\title{
Neoproterozoic Arc-Related Mafic Intrusions along the Northern Margin of South China: Implications for the Accretion of Rodinia
}

\author{
Mei-Fu Zhou, Allen K. Kennedy, ${ }^{1}$ Min Sun, John Malpas, and C. Michael Lesher ${ }^{2}$ \\ Department of Earth Sciences, University of Hong Kong, Hong Kong, China \\ (e-mail: mfzhou@hkucc.hku.hk)
}

\begin{abstract}
A B S T R A C T
South China has been considered as part of the Rodinian supercontinent during Neoproterozoic time, although its paleogeographic position within this supercontinent is still a matter of debate. The Wangjiangshan and Bijigou complexes along the northern margin of South China are among the largest mafic intrusions in China. New SHRIMP zircon U-Pb results indicate that these two intrusions have crystallization ages of $820 \mathrm{Ma}$ and $780 \mathrm{Ma}$, respectively. Enrichment of large ion lithophile and light rare earth elements and depletion of high field-strength elements in these intrusions suggest derivation from an active arc along a continental margin. This interpretation of these intrusions as part of a continental arc assemblage is in contrast with the previous view that they were products of a Neoproterozoic mantle plume that initiated the breakup of Rodinia. The presence of a Neoproterozoic magmatic arc suggests that Rodinian oceanic lithosphere was subducted beneath the (present) northern margin of South China and therefore that South China flanked the Rodinian ocean.
\end{abstract}

\section{Introduction}

Mantle-derived igneous complexes of 900-600 Ma age have been identified in West Africa and Brazil and define sutures between formerly isolated cratons or the outboard margins of cratons (Kroner et al. 1990; Abu El-Ela 1999; Hefferan et al. 2000). Their recognition is important for understanding the accretion and breakup of the Precambrian supercontinent, Rodinia (reviews in Hoffman 1999; Dalziel et al. 2000; Piper 2000). Tectonostratigraphic and paleomagnetic data suggest a link between South China and Rodinia (Li et al. 1995), and the extensive Neoproterozoic magmatism in South China has also been considered as evidence for correlation between South China, Australia, and Laurentia (Li et al. 1995, 1999). Li et al. (1999) further suggest that the $827 \mathrm{Ma}$ mafic dikes in the Sibao region of South China resemble those in south2002.

Manuscript received March 6, 2001; accepted January 10,

${ }^{1}$ SHRIMP II Laboratory, Curtin University of Technology, Perth, Australia.

${ }^{2}$ Mineral Exploration Research Centre, Laurentian University, Sudbury, Ontario, Canada.

eastern Australia and were products of the same mantle plume that initiated the breakup of Rodinia.

Some of the largest mafic/ultramafic intrusions in China occur along the northern margin of South China, within a continental rift zone proposed by Li et al. (1999). This article presents new major oxide, trace element, and $\mathrm{Sm} / \mathrm{Nd}$ and zircon $\mathrm{U} / \mathrm{Pb}$ isotopic data for these intrusions. These data indicate that these intrusions are derived from arcrelated, not rift-related, magmatism and that this occurred at ca. $820-780 \mathrm{Ma}$. This arc-related magmatism along the northern margin of South China provides important constraints on the position of South China in Rodinia.

\section{Geological Setting}

South China comprises the Yangtze Block in the northwest and the Cathaysian Block in the southeast, which were welded together ca. 820-870 Ma (Zhao and Cawood 1999 and references therein). South China is separated from North China by the Qinling orogenic belt (fig. 1), which was formed by the closure of the easternmost part of the Paleo-

[The Journal of Geology, 2002, volume 110, p. 611-618] @ 2002 by The University of Chicago. All rights reserved. 0022-1376/2002/11005-0008\$15.00 


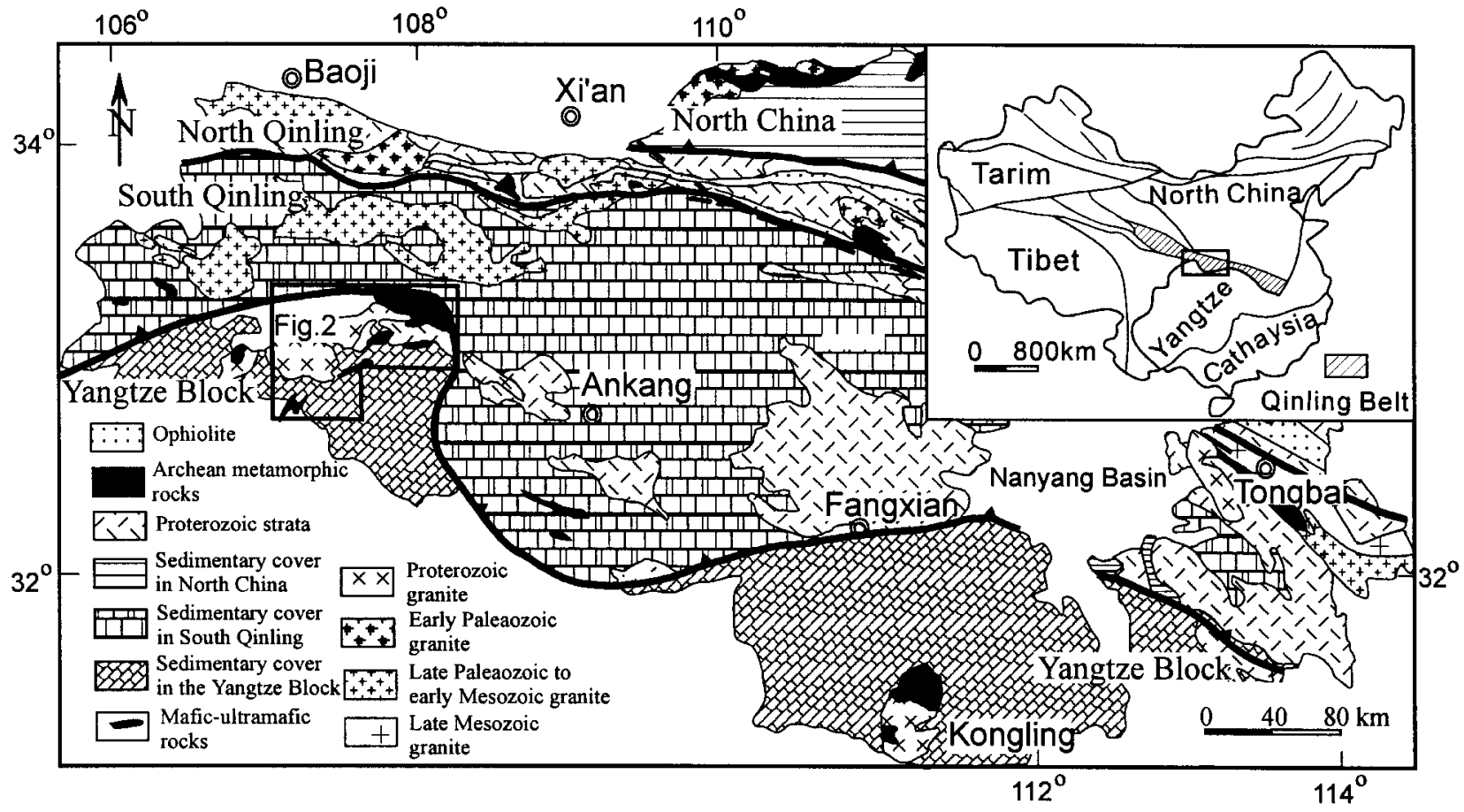

Figure 1. Regional geological map showing the relationship between North China, Qinling, and South China (modified from Meng and Zhang 2000).

tethyan ocean (Mattauer et al. 1985; Hsu et al. 1987). The Qinling belt extends eastward to the Dabie ultrahigh-pressure terrane and is divided into two tectonic units: the North Qinling and the South Qinling terranes. The North Qinling terrane has been interpreted as the southernmost active continental margin of North China, whereas the South Qinling terrane has been interpreted as the northernmost passive margin of South China (Gao et al. 1996). The Qinling belt resulted from the collision between North China and South China during the middle Paleozoic (Kroner et al. 1993; Gao et al. 1996; Zhang et al. 1997) or the Late Triassic (Hsu et al. 1987; Ames et al. 1993; Li et al. 1993; Yin and Nie 1996; Hacker et al. 2000). The Triassic collision was marked by the Mianlue suture, which separates the Yangtze Block and the South Qinling terrane (Meng and Zhang 2000).

The oldest basement rocks in the Yangtze Block are the $2.8 \mathrm{Ga}$ tonalite-trondhjemite-granodiorite (TTG) gneisses in the Kongling high-grade terrane (Qiu et al. 2000) and the poorly dated gneisses in the Kangding TTG complex along its western margin. The basement of the Yangtze Block comprises a lower Mesoproterozoic metasedimentary sequence of paragneiss and marble, overlain by a thick Middle Proterozoic supracrustal succession including komatiitic basalts erupted along continental rift zones (Zhou et al. 2000). The Late Sinian-Middle Triassic sedimentary cover consists of typical platform limestones, dolostones, shales, and sandstones, with Sinian tillites at the base and bauxite and coal measures in the lower unit of the Permian. The Upper Triassic and Jurassic cover consists predominantly of continental clastic rocks.

In the Hannan area on the northernmost margin of the Yangtze Block (figs. 1, 2), the Xixiang Group comprises a supracrustal sequence of tholeiites, andesites, dacites, pyroclastic rocks, graywackes, conglomerates, and arkoses. This sequence has a total thickness of over $4 \mathrm{~km}$ and was interpreted to have developed in an arc environment (Gao et al. 1990). The Xixiang Group was intruded by the Wangiiangshan and Bijigou mafic intrusions, as well as several tonalite, trondhjemite, and minor quartz diorite and granodiorite intrusions known as the Hannan granites. There are also some small K-feldspar granite intrusions. All of these rocks are covered by unmetamorphosed sedimentary rocks of Sinian age formed on a stable platform.

There are no reliable geochronological constraints on the age of magmatism in the region. Xia et al. (1988) reported a biotite ${ }^{40} \mathrm{Ar} /{ }^{39} \mathrm{Ar}$ plateau age 


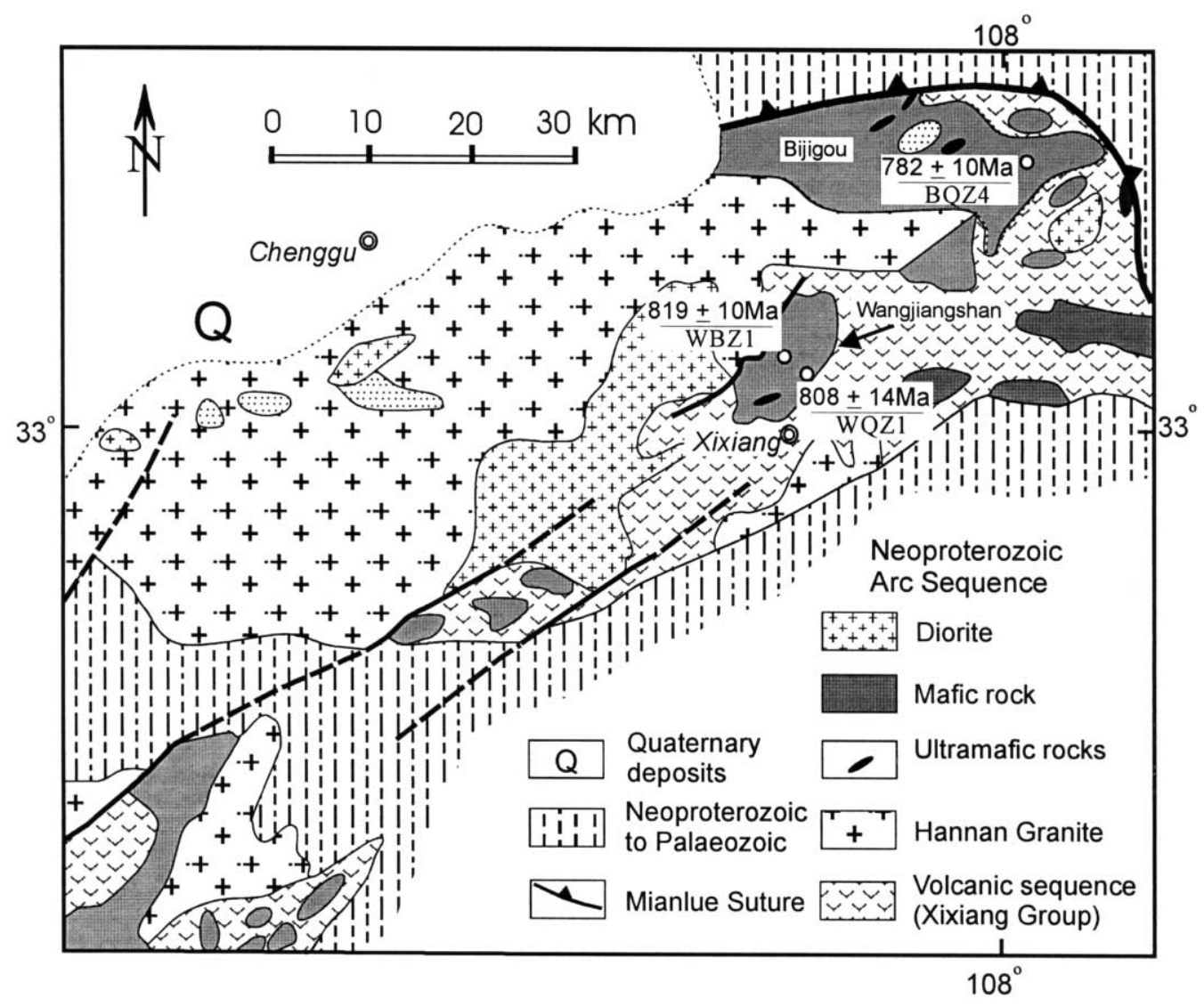

Figure 2. Geological map of the Hannan area, northern margin of the Yangtze Block, showing the distribution of mafic intrusions (after Xia et al. 1988; Gao et al. 1990).

of $1121 \mathrm{Ma}$ for the Wangiiangshan mafic intrusion, and Ling (1996) reported a ${ }^{207} \mathrm{~Pb} /{ }^{206} \mathrm{~Pb}$ single zircon evaporation age of $1010 \pm 16 \mathrm{Ma}$ for the Xixiang Group. Gao et al. (1990) considered all of the intrusive rocks and volcanic rocks to be comagmatic and interpreted the volcanic-intrusive magmatism as part of a continental arc built on the northern margin of the Yangtze Block.

\section{Mafic Layered Intrusions and Their Geochemistry}

The Wangjiangshan intrusion, which has an exposed area of over $100 \mathrm{~km}^{2}$, intrudes the Xixiang Group and has been intruded by the Hannan granites (fig. 2). This intrusion contains well-layered rock series, including a lower, 300-400-m-thick unit of pyroxenite and troctolite; a middle, 2000$\mathrm{m}$-thick unit of olivine gabbro and gabbro; and an upper, 100 -m-thick unit of gabbro and diorite. Disseminated sulfide-bearing rocks in the lower unit contain $0.20-0.37$ wt \% Cu and 0.10-0.17 wt \% Ni.
Magnetite and apatite-rich zones occur in the middle gabbro unit.

The Bijigou intrusion, which has an exposed area of more than $500 \mathrm{~km}^{2}$, consists of four lithological associations: an upper diorite unit, middle gabbro and noritic gabbro unit, a lower pyroxenite unit with minor dunite, harzburgite, troctolite, and anorthosite, and a basal breccia zone. Cr-magnetiterich zones occur in the lower ultramafic unit. A major magnetite-rich zone occurs in the middle gabbro unit.

The Wangjiangshan and Bijigou intrusions exhibit similar layering and share similar geochemical signatures. Olivines from the lower units of both intrusions have similar Fo values, ranging from Fo71 to Fo82. Major element geochemical data (table 1; available from The Journal of Geology's Data Depository upon request) indicate that both intrusions exhibit tholeiitic trends (fig. 3). The abundances of trace elements of the Wangjiangshan intrusion are consistent with magmatic differentiation of a tholeiitic magma; they are enriched in 


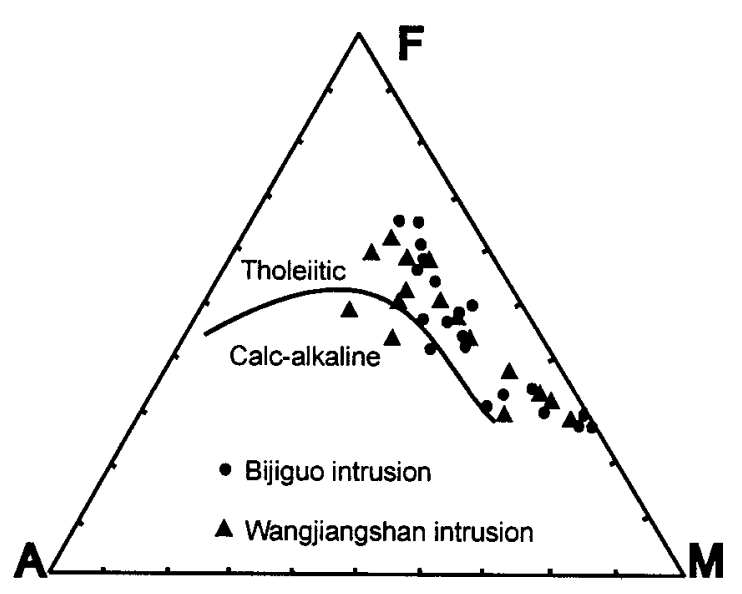

Figure 3. Whole-rock alkali $\left(\mathrm{Na}_{2} \mathrm{O}+\mathrm{K}_{2} \mathrm{O}\right)-\mathrm{FeO}_{\text {total }}-\mathrm{MgO}$ $(A F M)$ plots of rocks from the Wangjiangshan and Bijigou mafic intrusions. $A=\mathrm{Na}_{2} \mathrm{O}+\mathrm{K}_{2} \mathrm{O} ; \quad F=\mathrm{FeO}+\mathrm{Fe}_{2} \mathrm{O}_{3}$; and $M=\mathrm{MgO}$.

light rare earth elements (LREE) relative to medium rare earth elements (MREE) and heavy rare earth elements (HREE) and have variable Eu anomalies reflecting fractionation or accumulation of plagioclase (fig. 4). The primitive mantle-normalized, trace element spidergrams show enrichment in $\mathrm{Pb}$ and large ion lithophile elements (LILE: $\mathrm{Rb}, \mathrm{Cs}, \mathrm{Ba}$, $\mathrm{Th}$, and $\mathrm{U}$ ) relative to high field-strength elements (HFSE: $\mathrm{Nb}, \mathrm{Zr}, \mathrm{Hf}, \mathrm{Ti}$, and $\mathrm{Y}$ ) and REE (fig. 4). $\mathrm{Zr}$ and $\mathrm{Hf}$ are more depleted than Sm and Nd (fig. 4).

The $\epsilon_{\mathrm{Nd}}$ values for six samples from the Wangjiangshan intrusion range from +3.5 to +5.9 at 820 Ma (table 2). The depleted mantle model ages (TDM; De Paolo 1981; Liew and Hofmann 1988) range from $880 \mathrm{Ma}$ to $1470 \mathrm{Ma}$. These results, together with the major and trace element geochemical data, indicate that the Wangjiangshan intrusion was derived from magmas produced in the mantle with minor degrees of crustal contamination and are consistent with a model involving continental arc magmatism.

\section{SHRIMP Zircon Geochronology}

Analytical Methods. Zircons were separated using conventional heavy liquid and magnetic techniques. The zircons were mounted in epoxy and were polished and coated with gold. The mounts were then photographed in transmitted and reflected light for identification of analyzed grains. Cathodoluminescence (CL) images were obtained on a Philips XL30 SEM. The instrumental techniques for isotopic analysis of zircons using the SHRIMP II ion microprobe at the Curtin University of Technology are similar to those of Compston et al. (1984).

All isotopic measurements were reduced by offline computer programs using standard techniques. The calculation of ${ }^{206} \mathrm{~Pb} /{ }^{238} \mathrm{U}$ ages is based on the assumption that the bias in the measured ${ }^{206} \mathrm{~Pb} /{ }^{238} \mathrm{U}$ ratio relative to the true ratio can be described by the same power law relationship between ${ }^{206} \mathrm{~Pb} /{ }^{238} \mathrm{U}$ and $\mathrm{UO}^{+} / \mathrm{U}^{+}$for both the standard and sample. $\mathrm{Pb} /$ $\mathrm{U}$ ages are based on a value of $564 \mathrm{Ma}$ determined by conventional U-Pb analysis of the standard zircon $\mathrm{CZ} 3$. The ${ }^{206} \mathrm{~Pb} /{ }^{238} \mathrm{U}$ and ${ }^{207} \mathrm{~Pb} /{ }^{235} \mathrm{U}$ data have been corrected for the uncertainties associated with the measurements of the CZ3 standard. The uncertainties of ${ }^{207} \mathrm{~Pb} /{ }^{206} \mathrm{U}$ ages are independent of the standard analyses but are sensitive to the common $\mathrm{Pb}$ correction in low $\mathrm{U}$ zircons, especially those that are $<1000 \mathrm{Ma}$ in age. Because the ${ }^{207} \mathrm{~Pb} /{ }^{206} \mathrm{U}$
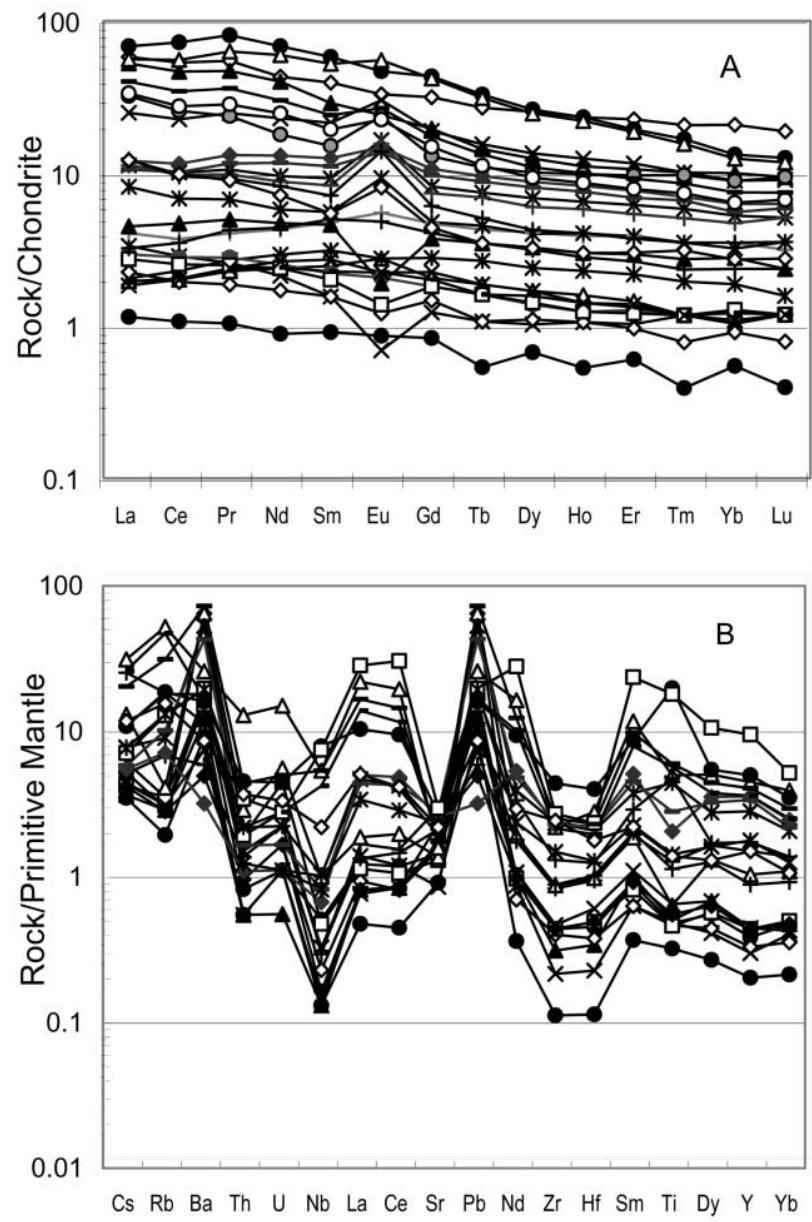

Figure 4. Chondrite-normalized REE patterns $(A)$ and trace element spidergram $(B)$ of the Wangiianshan intrusion. Primitive mantle values are from Sun and McDonough (1989). 
Table 2. Sm-Nd Isotopic Analytical Results of Rocks from the Wangiiangshan Intrusion, Northern Margin of South China

\begin{tabular}{|c|c|c|c|c|c|c|c|c|c|}
\hline Sample & Rock & $\mathrm{Sm}(\mathrm{ppm})$ & $\mathrm{Nd}(\mathrm{ppm})$ & ${ }^{147} \mathrm{Sm} /{ }^{144} \mathrm{Nd}$ & \multicolumn{2}{|c|}{${ }^{143} \mathrm{Sm} /{ }^{144} \mathrm{Nd}$} & $\epsilon_{\mathrm{Nd}(\mathrm{o})}$ & $\epsilon_{\mathrm{Nd}(\mathrm{T})}$ & $\overline{\mathrm{T}_{\mathrm{DM}}}$ \\
\hline$\overline{7^{\prime}-8}$ & Gabbro & 6.811 & 26.836 & .1534 & .512595 & \pm 6 & -.6 & 3.66 & 1.1 \\
\hline $7^{\prime}-37$ & Gabbro & 1.476 & 4.807 & .1858 & .512759 & \pm 10 & 2.59 & 3.5 & 1.47 \\
\hline $7^{\prime}-47$ & Gabbro & 7.863 & 33.291 & .1427 & .512535 & \pm 8 & -1.78 & 3.6 & 1.07 \\
\hline $1205-14$ & Gabbro & .643 & 1.926 & .2018 & .512966 & \pm 13 & 6.63 & 5.89 & .88 \\
\hline 1207-1 & Gabbro & .346 & 1.343 & .1553 & & $\ldots$ & $\ldots$ & & . \\
\hline $1207-21$ & Gabbro & 4.358 & 18.345 & .1435 & .512606 & \pm 9 & -.39 & 4.9 & .93 \\
\hline
\end{tabular}

ages are sensitive to the common $\mathrm{Pb}$ correction, the ${ }^{206} \mathrm{~Pb} /{ }^{238} \mathrm{U}$ age is normally preferred for young zircons. Common $\mathrm{Pb}$ was corrected using the 204 method discussed in Compston et al. (1984). U, Th, and $\mathrm{Pb}$ concentrations were calculated using the methods given in Claoue-Long et al. (1995).

Individual analyses (table 3; also available from the Journal's Data Depository) are presented as $1 \sigma$ error boxes on concordia plots; and uncertainties in mean ages are quoted at the $95 \%$ confidence level $(2 \sigma)$.

Results. Three samples were selected for zircon separation: WBZ1 (diorite) and WQZ1 (gabbro) from the Wangjiangshan intrusion, and BQZ4 (gabbro) from the Bijigou intrusion (fig. 5). More than 100 grains of zircon were recovered from each sample. All zircons are $40-100 \mu \mathrm{m}$ in size and are euhedral and prismatic in morphology. All crystals are free from obvious inclusions, but many show visible internal oscillatory zoning under CL imaging of sectioned grains.

Wangjiangshan Intrusion. Sample WBZ1 contains zircons with a variety of textures and morphologies, with complex internal structure. The internal complexity of the zircons does not affect the ages obtained from different grains. Cores, rims, high and low $U$ regions, and crystals of different shape all gave the same age within the uncertainties. The mean of 13 analyses gives a ${ }^{206} \mathrm{~Pb} /{ }^{238} \mathrm{U}$ age of $819 \pm 10 \mathrm{Ma}$, where the uncertainty is the $2 \sigma$ error on the mean. The results of these analyses are concordant. This age is the best estimate of the crystallization age of this sample.

Analyses of 18 spots on nine zircon grains from sample WQZ1 yielded four groups of ages. Two analyses have large uncertainties (spots 3 and 18), owing to their relatively low $U$ contents, and exhibit varying degrees of discordance on the concordia plot. Eleven of the data points define a weighted mean ${ }^{206} \mathrm{~Pb} /{ }^{238} \mathrm{U}$ age of $808 \pm 14 \mathrm{Ma}$. One single grain yielded a core ${ }^{206} \mathrm{~Pb} /{ }^{238} \mathrm{U}$ age of $815 \pm$ $19 \mathrm{Ma}$ (spot 16) and a rim age of $786 \pm 19 \mathrm{Ma}$ (spot 17). Another grain yielded a core age of $803 \pm 16$ $\mathrm{Ma}$ (spot 9) and a rim age of $756 \pm 18 \mathrm{Ma}$ (spot 10). The younger ages are attributed to postcrystalli- zation loss of radiogenic $\mathrm{Pb}$ because the rims have low Th and U contents. Therefore, the best estimate of the crystallization age of this sample is $808 \pm 14 \mathrm{Ma}$. This age assignment is consistent, within analytical uncertainties, with that for sample WBZ1.

Bijigou Intrusion. Analyses of 15 spots on 11 zircon grains from sample BQZ4 of the Bijigou intrusion, including core and rims, yielded the same age within the range of analytical uncertainties. The mean ${ }^{206} \mathrm{~Pb} /{ }^{238} \mathrm{U}$ age is $782 \pm 10 \mathrm{Ma}$, the mean ${ }^{207} \mathrm{~Pb} /$ ${ }^{235} \mathrm{U}$ age is $782 \pm 9 \mathrm{Ma}$, and the ${ }^{207} \mathrm{~Pb} /{ }^{206} \mathrm{U}$ age is $791 \pm 14 \mathrm{Ma}$. These data are consistent with a single age population of zircons. The $\chi^{2}$ value for the ${ }^{206} \mathrm{~Pb} /{ }^{238} \mathrm{U}$ and ${ }^{207} \mathrm{~Pb} /{ }^{235} \mathrm{U}$ ages is 1.02 . All the grains have similarly high $\mathrm{Th}$ and $\mathrm{U}$ contents and are considered magmatic. Thus, an age of $782 \mathrm{Ma}$ is interpreted as the crystallization age of the intrusion.

\section{Discussion}

The tectonic setting of the Wangjiangshan and Bijigou mafic intrusions has previously been described as a Neoproterozoic continental rift zone, and the intrusions are interpreted as products of a mantle plume that initiated the breakup of Rodinia (Li et al. 1999). These workers reported $825 \mathrm{Ma}$ mafic dikes in the Nanhua "rift zone" on the southeastern margin of the Yangtze Block and considered them a consequence of a mantle plume that also produced the Giadner dike swarms in Australia. However, there appears to be little other evidence of an $825 \mathrm{Ma}$ mantle plume in South China, and this concept was questioned by Zhao and Cawood (1999), who suggested that magmatism and metamorphism in the region is collision related and occurred at ca. $800 \mathrm{Ma}$.

Our new SHRIMP zircon data reveal that there was significant magmatic activity at $780-820 \mathrm{Ma}$ along the northernmost margin of South China. The LILE and LREE enrichment and HFSE depletion, along with the Sm-Nd isotopic signature of the mafic intrusions, demonstrate involvement of subduction-related components. Some of these fea- 

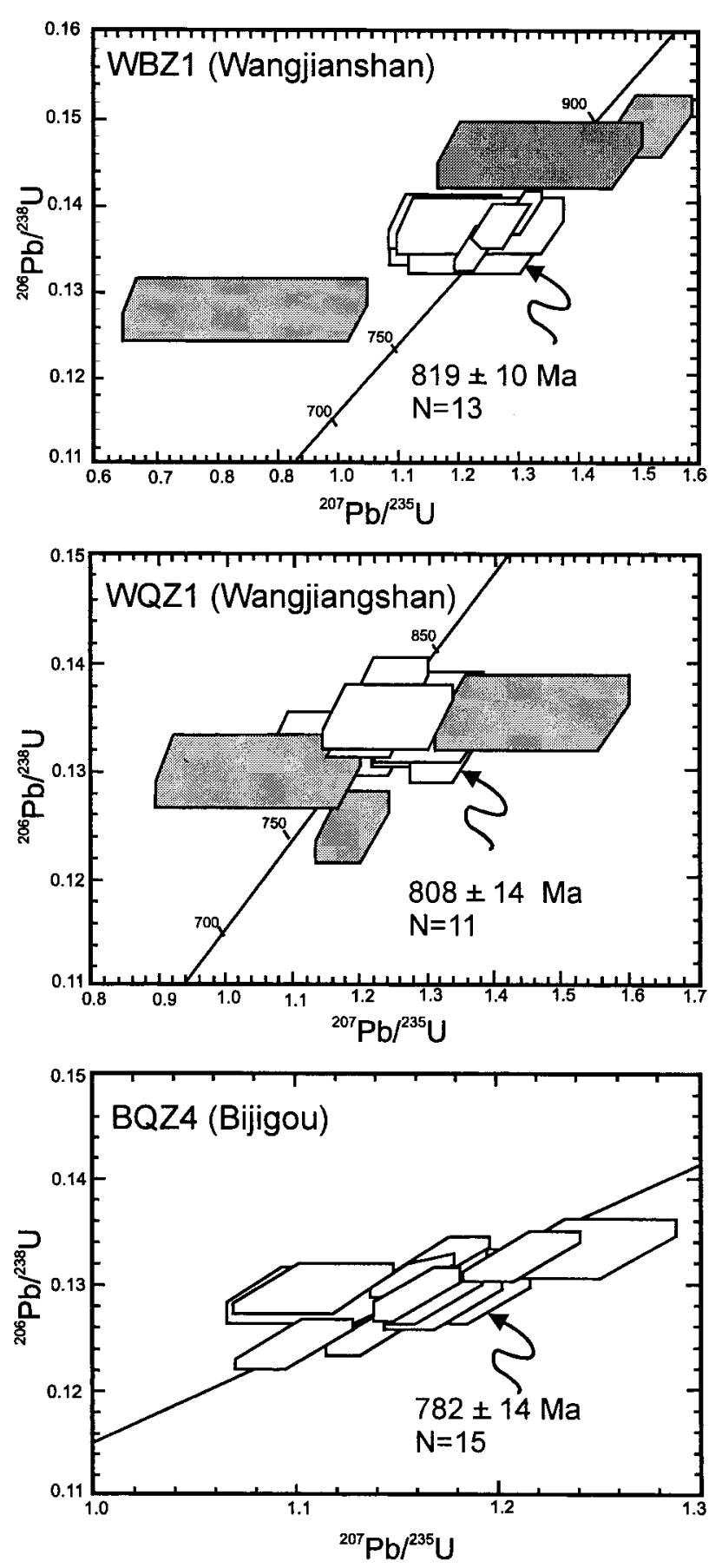

Figure 5. Concordia plot of zircon $\mathrm{U} / \mathrm{Pb}$ results of samples from the Wangjianshan and Bijigou intrusions.

tures may be explained by intracontinental, riftrelated (mantle plume) magmas derived from a subduction-modified lithospheric mantle (e.g., Sun and McDonough 1989). However, stronger depletion of $\mathrm{Zr}$ and $\mathrm{Hf}$ than $\mathrm{Nd}$ and $\mathrm{Sm}$ (fig. 4) cannot be attributed to mineral (e.g., clinopyroxene) frac- tionation because samples analyzed cover all rock types as shown by their variable chemistry. Such a depletion is not known in intraplate basalts, but this depletion, together with other geochemical features of the intrusions, are similar to those of island arc intrusions, indicating a subduction zone setting (e.g., Abu El-Ela 1999; Spandler et al. 2000).

In the Hannan area, the igneous assemblage was collectively termed the Hannan complex and includes the abundant granites and andesitic volcanic rocks (the Xixiang Group) (fig. 2). Although the timing of formation of these rocks is poorly constrained, it is possible that they may be part of a Neoproterozoic island arc built on the northern margin of South China.

The SHRIMP dating results reveal that the Bijigou intrusion is $40 \mathrm{~m}$.yr. younger than the Wangjiangshan intrusion situated farther south, and the age difference is significant enough to rule out a model in which these two intrusions represent a single magmatic event. We suggest that the mafic intrusions were derived from an arc magmatism and that this magmatism formed a magmatic arc built on the continental margin, plutonic portions of which are represented by the Wangjiangshan and Bijigou mafic intrusions. The younger age toward the north may have implications for the subduction polarity beneath the continental margin, although more data are clearly required to confirm this possibility.

Arc-related mafic intrusions have been described in California (Snoke et al. 1981), the New GuineaSolomon arc region (Whalen 1985), and the Aleutians (Kay and Kay 1988), but this is the first time they have been recognized in South China. Neoproterozoic subduction-related magmatism spans the period 900-600 Ma in "Pan-African" orogens, including those in South America, Northeast Africa, and Saudi Arabia (Stoeser and Camp 1985; Kroner et al. 1990; Abu El-Ela 1999). These arc-related terranes consist of metavolcanic and plutonic rocks of mafic to intermediate composition and associated metasedimentary rocks (Stoeser and Camp 1985) and have formed in convergent tectonic settings resulting from closure of ocean basins during the assembly of the Gondwana supercontinent. Although it is not known whether or not South China had any connection with these orogens, the presence of a magmatic arc along the northernmost margin of South China suggests that the Rodinian oceanic lithosphere was subducted beneath this margin and therefore that South China could not have lain between Australia and Laurentia, as previously proposed (Li et al. 1995). A more realistic scenario would be that South China was situated 
on the margin of Rodinia and perhaps north of Australia to allow subduction of the Rodinian oceanic lithosphere beneath the northern margin of South China. A similar scenario was suggested to explain the Neoproterozoic metamorphism in South China (Zhao and Cawood 1999).

Given the present evidence, it is not clear whether magmatism occurred as a continuous event between $820 \mathrm{Ma}$ and $780 \mathrm{Ma}$ or whether it occurred in two or more episodic events. The geochronological data reported here suggest that the initiation of arc magmatism in the Xixiang sequence, and presumably also the onset of subduction beneath it, may have occurred by at least 820-780 Ma. This magmatic activity along the northern margin of South China ceased before the early Paleozoic when the region became a passive margin. At this time (Late Neoproterozoic to Ordovician), South China, including the Yangtze and Cathaysia Blocks, rifted away from East Gondwanaland and Laurentia (Li et al. 1995, 1999). South China drifted toward North China, experienced rapid subsidence, and was covered by the thick Late Sinian-Cambrian succession of platformal carbonates and the unique, widespread, phosphorite deposits and black shales (Ma and Bai 1998 and references therein). This important Late Neoproterozoic-early Paleozoic tectonic event affected both North and South China.

\section{Conclusions}

The $820 \mathrm{Ma}$ and $780 \mathrm{Ma}$ mafic intrusions on the northern margin of South China are among the largest layered intrusions known in China and were derived from magmas that formed a continental arc. Their occurrence suggests that Rodinian oceanic lithosphere was subducted beneath the northern margin of South China during Neoproterozoic time. This magmatic arc relocates the paleotectonic setting of South China on the margin of Rodinia, perhaps to the north of Australia.

\section{A C K N O W L E D G M E N T S}

This study was substantially supported by a grant from the Research Grant Council of Hong Kong (P7301/99P to M.-F. Zhou, C. M. Lesher, and J. Malpas). Zircon analyses were carried out on the Sensitive High Resolution Ion Microprobe mass spectrometer (SHRIMP II) at the Curtin University of Technology, Australia. We appreciate thorough reviews by Z.-X. Li and S.-S. Sun, whose insights led to substantial improvements in this manuscript. We are grateful to G. C. Zhao, Y. F. Zheng, and an anonymous referee for providing useful comments on an earlier version of this article. Zhihua Yang (Xi'an College of Engineering) and Tai-Ping Zhao (Chinese Academy of Sciences) are thanked for leading field excursions to Qinling.

\section{R E F E R E N C E S C I T E D}

Abu El-Ela, F. F. 1999. Neoproterozoic tholeiitic arc plutonism: petrology of gabbroic intrusions in the ElAradiya area, Eastern Desert, Egypt. J. Afr. Earth Sci. 28:721-741.

Ames, L.; Tilton, G. R.; and Zhou, G. Z. 1993. Timing of collision of the Sino-Korean and Yangtze cratons: $\mathrm{U}-\mathrm{Pb}$ zircon dating of coesite-bearing eclogite. Geology 21:339-342.

Claoue-Long, J. C.; Compston, W.; Roberts, J.; and Fanning, C. M. 1995. Two Carboniferous ages: a comparison of SHRIMP zircon dating with conventional zircon ages and ${ }^{40} \mathrm{Ar} /{ }^{39} \mathrm{Ar}$ analyses. SEPM Spec. Publ. 54: 3-21.

Compston, W.; Williams, I. S.; and Meyer, C. 1984. U$\mathrm{Pb}$ geochronology of zircons from Lunar Breccia 73217 using a sensitive high mass-resolution ion microprobe. J. Geophys. Res. 89:525-534.

Dalziel, I. W. D; Mosher, S.; and Gahagan, L. M. 2000. Laurentia-Kalahari collision and the assembly of Rodinia. J. Geol. 108:499-513.

De Paolo, D. J. 1981. Trace element and isotopic effects of combined wallrock assimilation and fractional crystallization. Earth Planet. Sci. Lett. 53:189-202.
Gao, S.; Zhang, B. R.; and Li, Z. J. 1990. Geochemical evidence for Proterozoic continental arc and continental-margin rift magmatism along the northern margin of the Yangtze Craton, South China. Precambrian Res. 47:205-221.

Gao, S.; Zhang, B. R.; Li, Z. J.; Wang, D. P.; Ouyang, J. P.; and Xie, X. L. 1996. Geochemical evidence for Proterozoic tectonic evolution of the Qinling orogenic belt and its adjacent margins of North China and Yangtze cratons. Precambrian Res. 80:23-48.

Hacker, B. R.; Ratschbacher, L.; Webb, L.; McWilliams, M. O.; Ireland, T.; Calvert, A.; Dong, S. W.; Wenk, H. R.; and Chateigner, D. 2000. Exhumation of ultrahighpressure continental crust in east central China: Late Triassic-Early Jurassic tectonic unroofing. J. Geophys. Res. 105:13,339-13,364.

Hefferan, K. P.; Admou, H.; Karson, J. A.; and Saquaque, A. 2000. Anti-Atlas (Morocco) role in Neoproterozoic Western Gondwana reconstruction. Precambrian Res. 103:89-96.

Hoffman, P. F. 1999. The break-up of Rodinia, birth of Gondwana, true polar wander and the snowball Earth. J. Afr. Earth Sci. 28:17-33. 
Hsu, K. J.; Wang, Q. C.; Li, J. L.; Zhou, D.; and Sun, S. 1987. Tectonic evolution of Qinling Mountains, China. Eclogae Geol. Helv. 80:735-753.

Kay, R. W., and Kay, S. M. 1988. Crustal recycling and the Aleutian arc. Geochim. Cosmochim. Acta 52: 1351-1359.

Kroner, A.; Eyal, M.; and Eyal, Y. 1990. Early Pan-African evolution of the basement around Elat, Israel, and the Sinai Peninsula revealed by single-zircon evaporation dating, and implications for crustal accretion rates. Geology 18:545-548.

Kroner, A.; Zhang, G. W.; and Sun, Y. 1993. Granulites in the Tongbai area, Qingling belt, China: geochemistry, petrology and single zircon geochronology, and implications for tectonic evolution of eastern Asia. Tectonics 12:245-255.

Li, S.; Chen, Y.; Cong, B.; Zhang, Z.; Zhang, R.; Liou, D.; Hart, S. R.; and Ge, N. 1993. Collision of the North China and the Yangtze blocks and formation of coesite-bearing eclogites: timing and processes. Chem. Geol. 109:70-89.

Li, Z. X.; Li, X. H.; Kinny, P.; and Wang, J. 1999. The breakup of Rodinia: did it start with a mantle plume beneath South China? Earth Planet. Sci. Lett. 173: $171-181$.

Li, Z. X.; Zhang, L.; and Powell, C. M. 1995. South China in Rodinia: part of the missing link between AustraliaEast-Antarctica and Laurentia? Geology 23:407-410.

Liew, T. C., and Hofmann, A. W. 1988. Precambrian crustal components, plutonic assimilations, plate environment of the Hercynian fold belt of central Europe: indications from $\mathrm{Nd}$ and $\mathrm{Sr}$ isotopic study. Contrib. Mineral. Petrol. 98:129-138.

Ling, W. T. 1996. Isotopic geochronology and crustal accretion of the Proterozoic basement of the northern margin. I. Houhe and Xixiang Groups. Earth Sci. J. China Univ. Geosci. 21:491-194.

Ma, X., and Bai, J., eds. 1998. Precambrian crustal evolution of China. Berlin, Springer, $331 \mathrm{p}$.

Mattauer, M.; Matte, P.; Malavielle, P.; Tapponnier, P.; Maluski, H.; Xu, Z. Q.; Lu, Y. L.; and Tang, Y. Q. 1985. Tectonics of the Qingling belt: build-up and evolution of eastern Asia. Nature 317:496-500.

Meng, Q.-R., and Zhang, G.-W. 2000. Geologic framework and tectonic evolution of the Qinling orogen, central China. Tectonophysics 323:183-196.

Piper, J. D. A. 2000. The Neoproterozoic supercontinent: Rodinia or Palaepangaea. Earth Planet. Sci. Lett. 176: 131-146.
Qiu, Y. M.; Gao, S.; McNaughton, N. J.; Groves, D. I.; and Ling, W. 2000. First evidence of $>3.2$ Ga continental crust in the Yangtze Craton of South China and its implications for Archean crustal evolution and Phanerozoic tectonics. Geology 28:11-14.

Snoke, A. W.; Quick, J. E.; and Bowman, H. R. 1981. Bear Mountain igneous complex, Klamath Mts., California: an ultramafic to felsic calc-alkaline suite. J. Petrol. 22: 501-522.

Spandler, C. J.; Eggins, S. M.; Arculus, R. J.; and Mavrogenes, J. A. 2000. Using melt inclusions to determine parent-magma compositions of layered intrusions: application to the Greenhills complex (New Zealand), a platinum group minerals-bearing, islandarc intrusion. Geology 28:991-994.

Stoeser, D. B., and Camp, V. E. 1985. Pan-African microplate accretion of the Arabian Shield. Geol. Soc. Am. Bull. 96:817-826.

Sun, S.-S., and McDonough, W. F. 1989. Chemical and isotopic systematics of oceanic basalts: implications for mantle composition and processes. In Saunders, A. D., and Norry, M. J., eds. Magmatism in the ocean basins. Geol. Soc. Spec. Publ. 42:313-345.

Whalen, J. B. 1985. Geochemistry of an island-arc plutonic suite: the Uasilau-Yau intrusive complex, New Britain, Papua New Guinea. J. Petrol. 26:603-632.

Xia, Z.; Luo, C.; Wang, J.; Liu, W.; Zhang, G.; and Li, Z. 1988. An example of polyperiodical pulses and intermingling of magma-Wangjiangshan basic complex intrusion. Bull. Xian Inst. Geol. 22:1-120 (in Chinese).

Yin, A., and Nie, S. 1996. A Phanerozoic palinspastic reconstruction of China and its neighboring regions. In Tectonic evolution of Asia. Yin, A., and Harrison, T. M., eds. New York, Cambridge University Press, p. 442-485.

Zhang, H. F.; Gao, S.; Zhang, B. R.; Luo, T. C.; and Lin, W. L. 1997. $\mathrm{Pb}$ isotopes of granitoids suggest Devonian accretion of Yangtze (South China) craton to North China craton. Geology 25:1015-1018.

Zhao, G., and Cawood, P. A. 1999. Tectonothermal evolution of the Mayuan assemblage in the Cathaysia Block: implications for Neoproterozoic collisionrelated assembly of the South China Craton. Am. J. Sci. 299:309-339.

Zhou, M.-F.; Zhao, T.-P.; Malpas, J.; and Sun, M. 2000. Crustal-contaminated komatiitic basalts in southern China: products of Proterozoic mantle plume underneath the Yangtze Block. Precambrian Res. 103: 175-189. 